\title{
Evaluation of a drug \& alcohol primary health care team
}

\author{
Dr Robert Patton \\ National Addiction Centre, King's College London
}

\section{Summary}

As part of an ongoing assessment of the physical health needs of injecting drug users during 2005, all 167 general practices in the Lambeth, Southwark \& Lewisham (LSL) area were sent a questionnaire. The results indicate that the majority of IDUs visited the surgery because of DVT, pregnancy, chest infections or skin ulceration, and the GPs themselves opportunistically identified more serious problems such as $B B V$ 's and Liver problems. Interestingly we found significant variation in the rate of opportunistic detection between PCTs.

Many practices indicated that health promotion activity would benefit their IDU clients, in particular issues related to smoking and drinking, as well as dental health, diet and exercise needed to be addressed. In general it was felt that a nurse led resource integrated into existing services, such as that offered by the Drug and Alcohol Health Care Team, would be of greatest benefit to IDU clients. 


\section{Methods}

Questionnaires were sent to all 167 GP practices in the three boroughs area. No follow-up was undertaken.

\section{Results}

A total of 71 practices returned questionnaires (42.5\% response rate).

\section{Service users and service utilisation}

Levels of substance misuse were high, with over $70 \%$ of all practices reporting five or more crack, IDU or combination patients. Only one practice indicated that they had no IDU or crack users registered. Distribution of users was even across the three boroughs; however Lewisham does appear to have significantly lower levels of crack users in contact with primary care services than Lambeth or Southwark.

Table 1.0 Proportion of practices with 5 or more drug users

\begin{tabular}{|l|c|c|c|}
\hline & Lambeth & Southwark & Lewisham \\
\hline IDU & $78 \%$ & $69 \%$ & $54 \%$ \\
\hline crack & $78 \%$ & $83 \%$ & $40 \% * *$ \\
\hline $\begin{array}{l}\text { IDU and crack } \\
\text { users }\end{array}$ & $81 \%$ & $63 \%$ & $47 \%$ \\
$* * \mathrm{p}<0.01$ & & \\
\hline
\end{tabular}

Practices reported moderate levels of service use by drug users, with most practices indicating that they saw between one and five users per month. However, practices in Lambeth were more likely than Lewisham or Southwark to see ten or more patients per month.

\section{Health problems}

Respondents were asked to indicate which physical health problems patients commonly presented with, and which conditions were usually identified by the doctor. Overall our list of physical health problems was acceptable to the GPs, with $100 \%$ response to all items.

Table 2.0 Physical Health Problems

\begin{tabular}{|l|c|c|}
\hline \multicolumn{1}{|c|}{ CONDITION } & $\begin{array}{c}\text { Patient } \\
\text { Presents }\end{array}$ & $\begin{array}{c}\text { Dr } \\
\text { identifies }\end{array}$ \\
\hline Mental Health Problems & $75 \%$ & $75 \%$ \\
\hline Deep Vein Thrombosis & $64 \%$ & $39 \% \%^{* *}$ \\
\hline Skin Abscesses / Ulceration & $89 \%$ & $44 \% \%^{* *}$ \\
\hline
\end{tabular}




\begin{tabular}{|l|c|c|}
\hline Self Neglect & $42 \%$ & $80 \% * *$ \\
\hline Liver Problems & $31 \%$ & $79 \% * *$ \\
\hline HIV & $31 \%$ & $76 \% * *$ \\
\hline HBV (Hepatitis B) & $36 \%$ & $81 \% \%^{* *}$ \\
\hline HCV (Hepatitis C) & $36 \%$ & $84 \% \%^{* *}$ \\
\hline TB (Tuberculosis) & $25 \%$ & $67 \% * *$ \\
\hline Pregnancy & $74 \%$ & $43 \% \%^{* *}$ \\
\hline STI (Sexually Transmitted Infection) & $64 \%$ & $56 \% *$ \\
\hline Nutritional Problems & $46 \%$ & $71 \% \%^{* *}$ \\
\hline Chest Infection & $74 \%$ & $60 \% *$ \\
\hline
\end{tabular}

$* \mathrm{p}<0.05, * * \mathrm{p}<0.01$

GPs opportunistically identify most of the problems that IDU and crack using patients present with, however there are distinct conditions that are usually identified by the patients themselves, these are: DVT, pregnancy, chest infections, and skin ulceration.

For certain conditions (in particular communicable disease) there were distinct and significant differences between boroughs in the proportion of practices that indicated the GP was likely to identify, or that the patient presented.

Table 3.0a Proportion of practices indicating "Dr Identifies"

\begin{tabular}{|l|c|c|c|}
\hline & Lambeth & Southwark & Lewisham \\
\hline HIV & $78 \%$ & $52 \%$ & $92 \%^{* *}$ \\
\hline HBV & $74 \%$ & $67 \%$ & $100 \%^{* *}$ \\
\hline HCV & $87 \%$ & $67 \%$ & $96 \%^{*}$ \\
\hline TB & $74 \%$ & $43 \%$ & $74 \%^{*}$ \\
\hline
\end{tabular}

$* \mathrm{p}<0.05, * * \mathrm{p}<0.01$

Table 3.0b Proportion of practices indicating "Patient presents"

\begin{tabular}{|l|c|c|c|}
\hline & Lambeth & Southwark & Lewisham \\
\hline STI & $74 \%$ & $43 \%$ & $74 \% *$ \\
\hline $\begin{array}{l}\text { Nutritional } \\
\text { Problems }\end{array}$ & $56 \%$ & $57 \%$ & $25 \% *$ \\
\hline
\end{tabular}

$* \mathrm{p}<0.05, * * \mathrm{p}<0.01$ 
$79 \%$ of practices indicated that patients were willing to disclose their health needs. There were no significant differences between the three boroughs on this item.

Practices were asked to list any other physical health needs that were not addressed by patients. Responses to this item were low, with 31 practices (44\%) offering a total of 33 suggestions.

Participants indicated a range of physical health needs that were not currently addressed by their patients. These included: alcohol related problems $(27 \%)$, dental problems (18\%), smoking related issues (12\%), asthma (9\%) and exercise (6\%). In addition some practices suggested that patients housing needs might be related to their physical health problems and that these needs should be considered.

$69 \%$ of practices offered suggestions as what sort of health care services might be of benefit to this patient group. Over $1 / 3$ thought that some sort of integrated service would be appropriate with over half of these indicating that a nurse led programme would be most beneficial. Other suggestions included Sexual Health Services (13\%), Alcohol Detoxification (13\%), Dual Diagnosis services (10\%) and Counselling $(10 \%)$.

Most practices indicated that they would be willing to help contact patients to further explore their physical health needs (64\%). However they were not interested in helping to develop a common assessment tool $(35 \%)$ but almost every practice would be interested in using such a tool $(80 \%)$.

In addition to the GP survey, data was also collected from DTTO clients. In total the records of 29 DTTO clients were examined, $72 \%$ were male. The age range of clients ranged from $23-53$ years, with an average age of 34.7 years.

The majority of clients (41\%) lived in public rented accommodation (council), 14\% had private rented, 14\% owner / occupied, 10\% NFA and $7 \%$ were resident in hostel accommodation. $17 \%$ of all clients lived alone. All those recorded as NFA lived with friends. Of those described as owning accommodation, two thirds were in fact living with their parents.

\section{Alcohol and Illicit drug use}

Alcohol, Cannabis, Heroin and Crack Cocaine were all used by DTTO clients. 
Alcohol consumption: Half of the sample had consumed alcohol on at least one occasion in the preceding month, with $60 \%$ of those drinking every day. Clients spent $£ 2-£ 20$ per drinking day on alcohol (average $£ 6.10$ ), and $£ 8$ - 2240 over the month (average $£ 155.90$ ).

Cannabis: One in three clients had smoked cannabis during the last 30 days, $50 \%$ of those smoked cannabis every day, $50 \%$ also admitted to smoking three or more joints per day. Clients spent $£ 2-£ 10$ per day (average £6.90) and $£ 16-£ 300$ per month (average $£ 155.90$ ).

Heroin: $86 \%$ of clients had used heroin in the last 30 days, $56 \%$ of these had used on at least one occasion every day. Most clients who had taken heroin did so on a single occasion on each day that they used, however $30 \%$ used heroin twice or more per day. Clients spent $£ 5-£ 70$ per day on heroin (average $£ 21.70$ ) and $£ 30-£ 2100$ per month (average $£ 550.30$ ). Most clients either injected $(50 \%)$ or smoked $(46 \%)$ heroin. A small number took it orally (4\%).

Crack Cocaine: $76 \%$ of DTTO clients had used crack on one or more occasion in the last 30 days, $27 \%$ of those had taken it every day. $90 \%$ of clients used crack at least once per week. $70 \%$ of those who took crack had two or more hits per occasion. Clients spent $£ 5-£ 100$ per day on crack (average $£ 25.00$ ), and $£ 10$ - $£ 3000$ per month (average $£ 500.00$ ). Most clients smoked their crack (86\%), with the remainder injecting.

Cocaine: Only one client was recorded as using cocaine.

Amphetamines: Only one client was recorded as using amphetamines.

Ecstasy: Only one client was recorded as using ecstasy.

Solvents: There was no record of solvent use for any client.

LSD: There was no record of LSD use for any client.

Benzodiazepines: Two clients were recorded as using benzodiazepines.

During the preceding month DTTO clients spent $£ 0$ - $£ 5100$ on alcohol and illicit substances (average £906.90)

\section{Injecting behaviour and related problems}


$54 \%$ of clients inject drugs, with $85 \%$ of these admitting to having injected in the last week. One in five clients used high risk injection sites and $27 \%$ shared needles or other paraphernalia. Three quarters of injectors used needle exchange services, and $100 \%$ had received harm minimisation advice.

$70 \%$ of DTTO clients had experienced injecting related problems in the past, $15 \%$ in the recent past. $15 \%$ of clients were described as having urgent injection related problems.

The most common injection related problems were abscess (40\%), DVT $(20 \%)$ and Infection $(13 \%)$.

\section{Sexual Health}

$70 \%$ of clients had a partner and $54 \%$ were currently sexually active. Of these, however, only $25 \%$ used contraception (all sexually active female clients indicated that they used some form of contraception). A third of all clients had contracted a STI at some point.

$80 \%$ of female DTTO clients had had a cervical smear test, and $60 \%$ had undergone breast examination.

$57 \%$ of male clients had had a testicular examination.

\section{Mental Health}

$8 \%$ of clients had a recent history of self harm, and a further $8 \%$ had taken a deliberate overdose. In total $16 \%$ of clients had made some sort of suicide attempt.

$12.5 \%$ of clients had a familial history of psychiatric illness. Two thirds of clients who had deliberately overdosed or made some other suicide attempt had a family history of psychiatric illness.

\section{Physical Health}

The DTTO notes examined had no record of Blood Pressure, Pulse, Weight, Blood Methadone or Blood Alcohol levels.

The following table illustrates the proportion of DTTO clients who had reported a specific medical condition, and other general health problems:

\begin{tabular}{|l|l||}
\hline & \\
\hline Asthma & $35 \%$ \\
\hline
\end{tabular}




\begin{tabular}{||l|l||}
\hline Bronchitis & $13 \%$ \\
\hline $\begin{array}{l}\text { Neurological } \\
\text { problems }\end{array}$ & $9 \%$ \\
\hline Cancer & $9 \%$ \\
\hline Heart problems & $5 \%$ \\
\hline Liver problems & $4 \%$ \\
\hline & \\
\hline Sleep problems & $60 \%$ \\
\hline Dental problems & $50 \%$ \\
\hline Hospital admission & $50 \%$ \\
\hline Allergies & $33 \%$ \\
\hline Poor Diet & $20 \%$ \\
\hline
\end{tabular}

Half of the clients reported that they had undergone surgery, and of these a quarter was for hernia operations.

Of those clients that indicated an allergy, $70 \%$ reported that they were allergic to penicillin.

\section{Blood Bourne Virus's}

$70 \%$ of clients had been tested for HBV, $17 \%$ within the last 12 months. Of those tested, $67 \%$ had been vaccinated, $85 \%$ of vaccinations were before 2003. 65\% had been tested for $\mathrm{HCV}, 18 \%$ within the last 12 months. $64 \%$ had been tested for HIV, $15 \%$ within the last 12 months.

\section{Contact with external services}

$10 \%$ of clients were in contact with social services, $7 \%$ with hostels / day centres and $3 \%$ with community mental health services.

\section{DAHCT Client Questionnaire - survey results}

\section{Demographics}

Between March 2005 and April 2006, 107 clients, from 8 centres, were assessed using the DAHCT client questionnaire. 


\begin{tabular}{|c|c|c|c|c|c|}
\hline \multicolumn{6}{|c|}{ Location } \\
\hline & & Frequency & Percent & Valid Percent & $\begin{array}{c}\text { Cumulative } \\
\text { Percent }\end{array}$ \\
\hline \multirow[t]{9}{*}{ Valid } & Stockwell Project & 26 & 24.3 & 24.3 & 24.3 \\
\hline & Evolve & 27 & 25.2 & 25.2 & 49.5 \\
\hline & Quantum & 10 & 9.3 & 9.3 & 58.9 \\
\hline & Equinox & 3 & 2.8 & 2.8 & 61.7 \\
\hline & Kappa & 9 & 8.4 & 8.4 & 70.1 \\
\hline & BCDAT & 7 & 6.5 & 6.5 & 76.6 \\
\hline & Pavillion & 11 & 10.3 & 10.3 & 86.9 \\
\hline & ARP & 14 & 13.1 & 13.1 & 100.0 \\
\hline & Total & 107 & 100.0 & 100.0 & \\
\hline
\end{tabular}

Two thirds of the clients were male $(\mathrm{N}=71)$. The age of clients ranged from $22-73$ years, with an average age of 38 .

\begin{tabular}{|c|c|c|c|c|c|}
\hline \multicolumn{6}{|c|}{ Ethnicity } \\
\hline & & Frequency & Percent & Valid Percent & $\begin{array}{c}\text { Cumulative } \\
\text { Percent }\end{array}$ \\
\hline \multirow[t]{10}{*}{ Valid } & White Italian & 6 & 5.6 & 5.8 & 5.8 \\
\hline & White British & 52 & 48.6 & 50.0 & 55.8 \\
\hline & Cypriot & 1 & .9 & 1.0 & 56.7 \\
\hline & Portugese & 11 & 10.3 & 10.6 & 67.3 \\
\hline & Black British & 19 & 17.8 & 18.3 & 85.6 \\
\hline & Russian & 1 & .9 & 1.0 & 86.5 \\
\hline & Black Caribbeen & 4 & 3.7 & 3.8 & 90.4 \\
\hline & White European & 6 & 5.6 & 5.8 & 96.2 \\
\hline & African & 4 & 3.7 & 3.8 & 100.0 \\
\hline & Total & 104 & 97.2 & 100.0 & \\
\hline Missing & System & 3 & 2.8 & & \\
\hline Total & & 107 & 100.0 & & \\
\hline
\end{tabular}

Thirty clients (28\%) described themselves as homeless.

The majority of clients were registered with a GP, with just 13 (12\%) not registered.

\section{Body Mass Index}

Almost 1/3 of clients were overweight. 


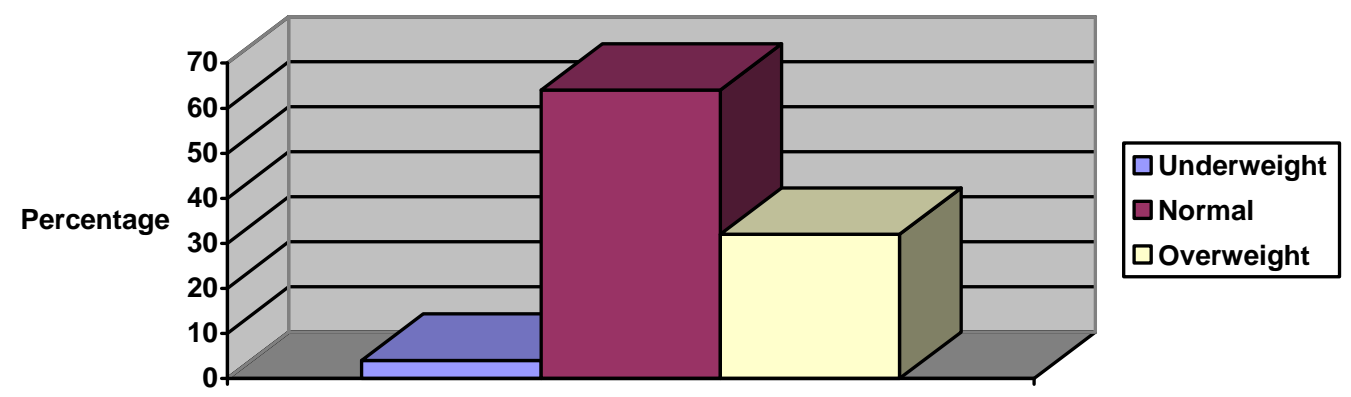

BMlstatus

\begin{tabular}{|ll|r|r|r|r|}
\hline & & & & Cumulative \\
& & Frequency & Percent & Valid Percent & \multicolumn{1}{c|}{ Percent } \\
\hline Valid & Normal & 64 & 59.8 & 64.0 & 64.0 \\
& Overweight & 32 & 29.9 & 32.0 & 96.0 \\
& Underweight & 4 & 3.7 & 4.0 & 100.0 \\
& Total & 100 & 93.5 & 100.0 & \\
Missing & System & 7 & 6.5 & & \\
Total & & 107 & 100.0 & & \\
\hline
\end{tabular}

\section{Physical Health}

Almost a quarter of all clients had a history of Asthma or Liver Problems. Clients with Bronchial or Liver problems were less likely to have sought treatment from their GP.

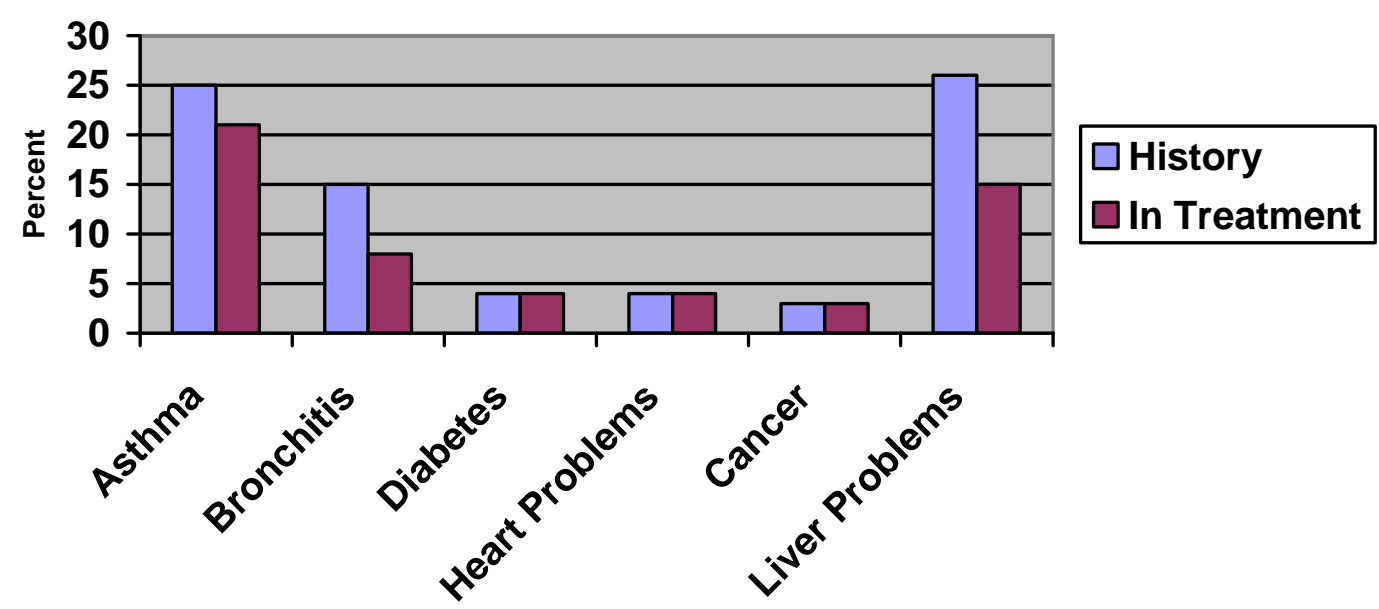




\section{Dental Health}

One third of all clients had had problems with their teeth. Almost half $(45 \%)$ were registered with a dentist.

Teeth * Dent_Reg Crosstabulation

\begin{tabular}{|c|c|c|c|c|c|}
\hline & \multicolumn{2}{|c|}{ Dent Reg } & \multirow[b]{2}{*}{ Total } \\
\hline & & & No & Yes & \\
\hline \multirow[t]{4}{*}{ Teeth } & No & Count & 12 & 33 & 45 \\
\hline & & $\%$ within Teeth & $26.7 \%$ & $73.3 \%$ & $100.0 \%$ \\
\hline & Yes & Count & 20 & 14 & 34 \\
\hline & & $\%$ within Teeth & $58.8 \%$ & $41.2 \%$ & $100.0 \%$ \\
\hline \multirow[t]{2}{*}{ Total } & & Count & 32 & 47 & 79 \\
\hline & & $\%$ within Teeth & $40.5 \%$ & $59.5 \%$ & $100.0 \%$ \\
\hline
\end{tabular}

\section{Mental Health}

Depression and Anxiety were the most commonly reported psychological problems.

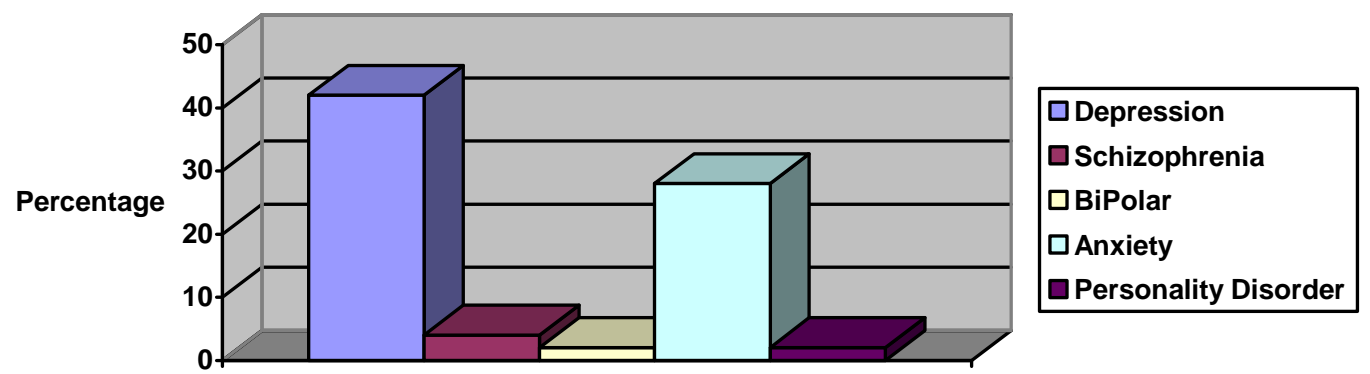

\section{Sexual Health}

Almost two thirds of clients were aware of GUM clinic services.

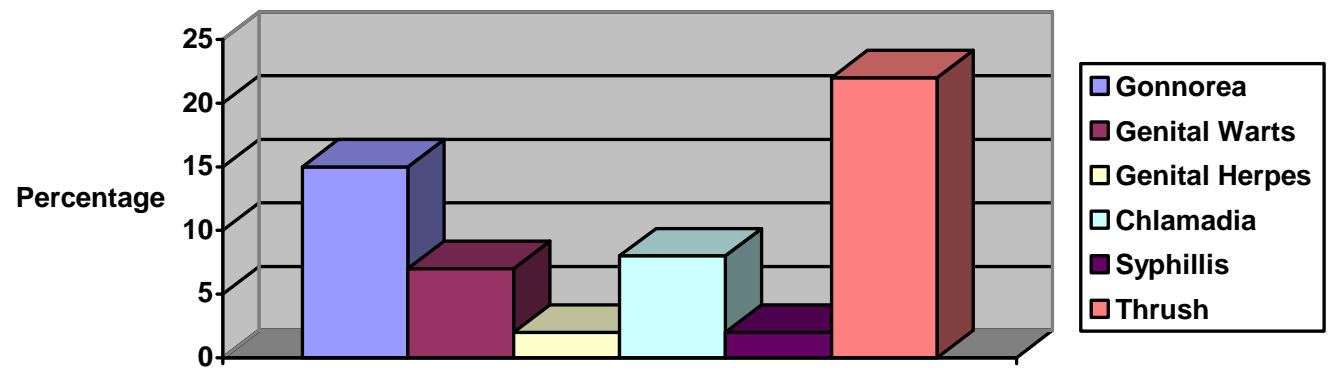




\section{Alcohol and Tobacco use}

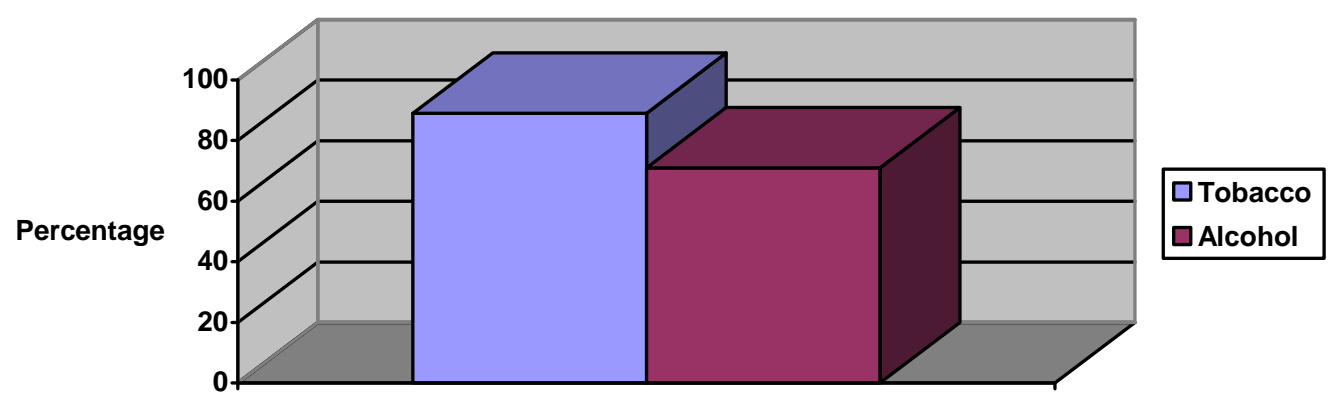

The majority of clients smoke (89\%) and consume alcohol (71\%)."

Current smokers $(\mathrm{n}=71)$ consumed between 2 and 50 cigarettes per day, with an average of 17 cigarettes per day.

Quit * Cesation Crosstabulation

\begin{tabular}{|lll|r|r|r|}
\hline \multirow{2}{*}{} & & \multicolumn{2}{|c|}{ Cesation } & \multirow{2}{*}{ Total } \\
\cline { 3 - 4 } & & \multicolumn{1}{|c|}{ No } & \multicolumn{1}{c|}{ Yes } & \multicolumn{1}{c|}{28} \\
& No & Count & 15 & 13 & $100.0 \%$ \\
\cline { 3 - 4 } & & $\%$ within Quit & $53.6 \%$ & $46.4 \%$ & $100.0 \%$ \\
& Yes & Count & 20 & 23 & 43 \\
& & $\%$ within Quit & $46.5 \%$ & $53.5 \%$ & $100.0 \%$ \\
\hline Total & & Count & 35 & 36 & 71 \\
& & \% within Quit & $49.3 \%$ & $50.7 \%$ & $100.0 \%$ \\
\hline
\end{tabular}

Sixty percent of current smokers wanted to quit, of these about $1 / 2$ were aware of local smoking cessation programmes.

Drinkers $(n=58)$ consumed between 2 and 50 units per day, with an average consumption of 13 units per day.

Gender * Hazardous Crosstabulation

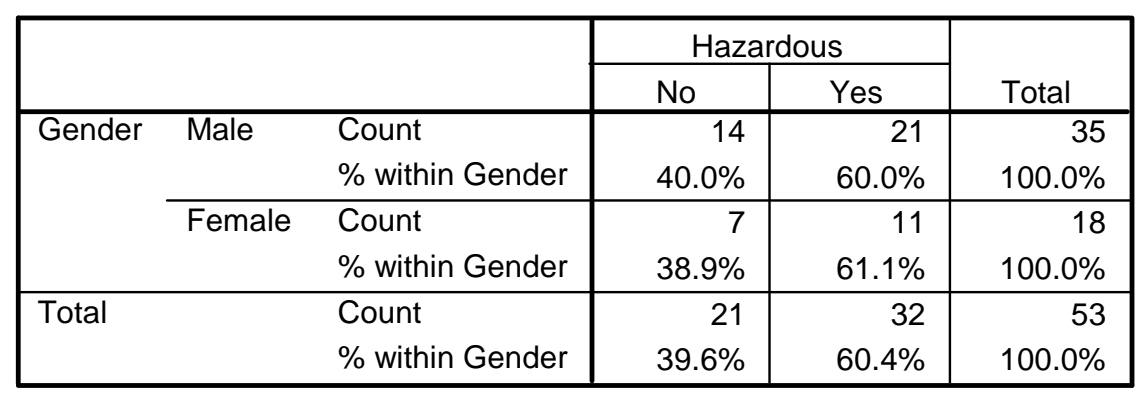

Data on drug usage was collected from a total of 83 clients. 
Sixty percent of all Male and all Female clients were hazardous drinkers.

Hazardous * Alc_Prob Crosstabulation

\begin{tabular}{|c|c|c|c|c|c|}
\hline & \multicolumn{2}{|c|}{ Alc Prob } & \multirow[b]{2}{*}{ Total } \\
\hline & & & No & Yes & \\
\hline \multirow[t]{4}{*}{ Hazardous } & No & Count & 19 & 2 & 21 \\
\hline & & $\%$ within Hazardous & $90.5 \%$ & $9.5 \%$ & $100.0 \%$ \\
\hline & Yes & Count & 12 & 18 & 30 \\
\hline & & $\%$ within Hazardous & $40.0 \%$ & $60.0 \%$ & $100.0 \%$ \\
\hline \multirow[t]{2}{*}{ Total } & & Count & 31 & 20 & 51 \\
\hline & & \% within Hazardous & $60.8 \%$ & $39.2 \%$ & $100.0 \%$ \\
\hline
\end{tabular}

Sixty percent of hazardous drinkers regarded themselves as having an alcohol problem.

\section{Drug Use in the previous month}

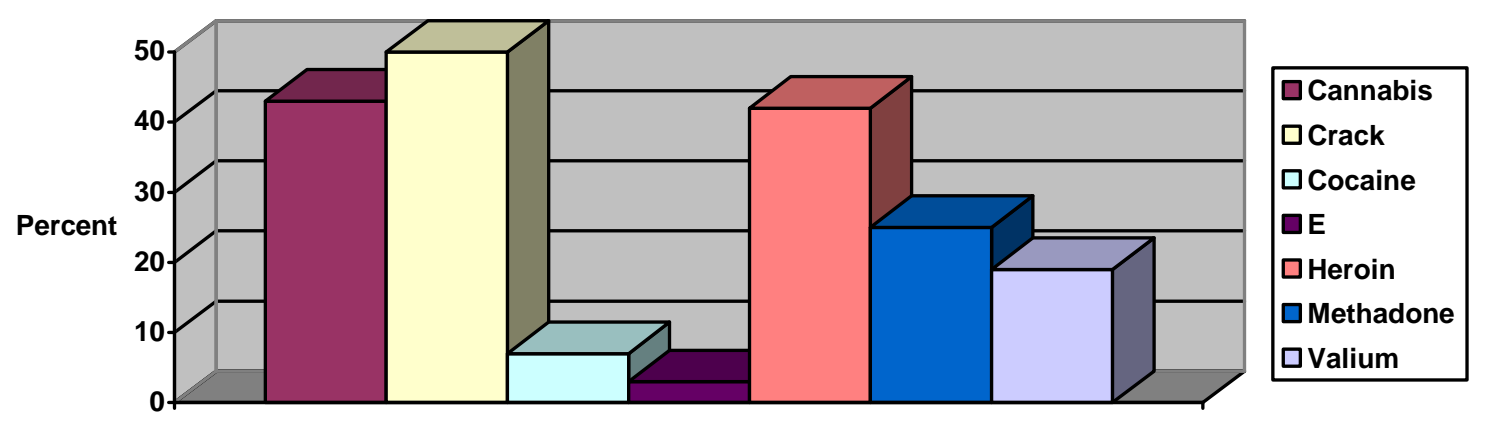

Seventy percent of clients smoked tobacco. Half of all clients used crack cocaine.

More than half of all clients (54\%) admitted to having injected drugs. Of these, three quarters had shared injecting equipment.

Two thirds of clients were aware of needle exchange services. 
Almost every client who indicated that they had injected drugs was aware of a needle exchange service they had access to.

IDU * NX_aware Crosstabulation

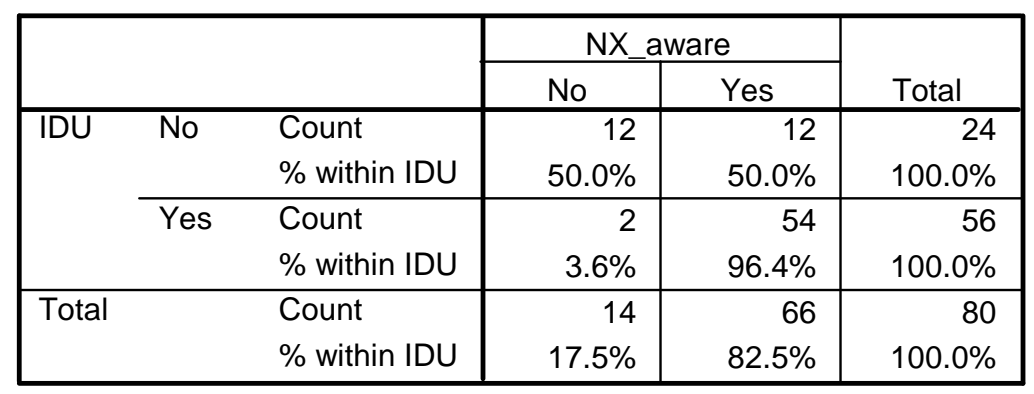

\section{Drug related health conditions}
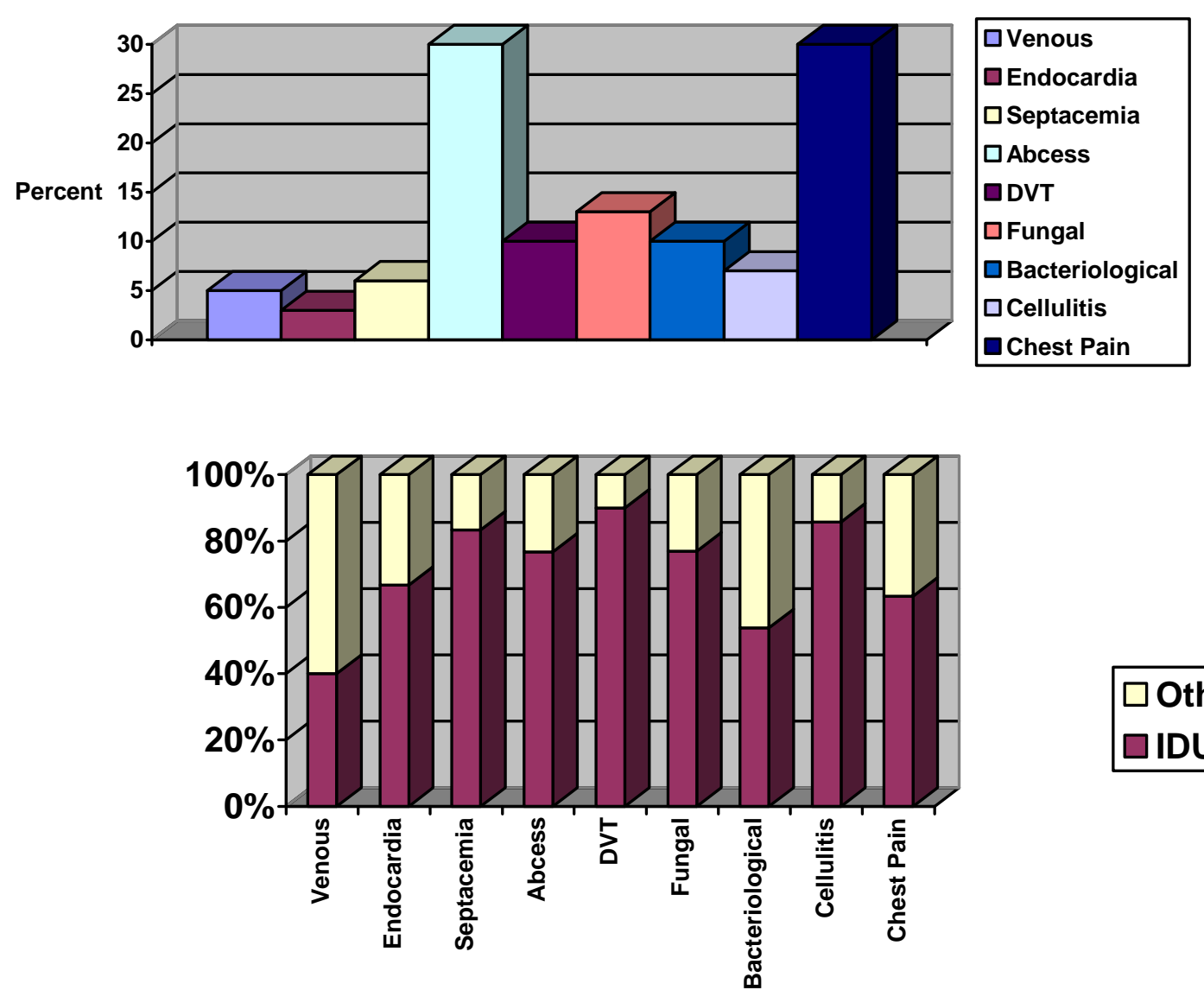


\section{Infections}

Almost one third of all clients had been diagnosed as being Hepatitis $\mathrm{C}$ positive.

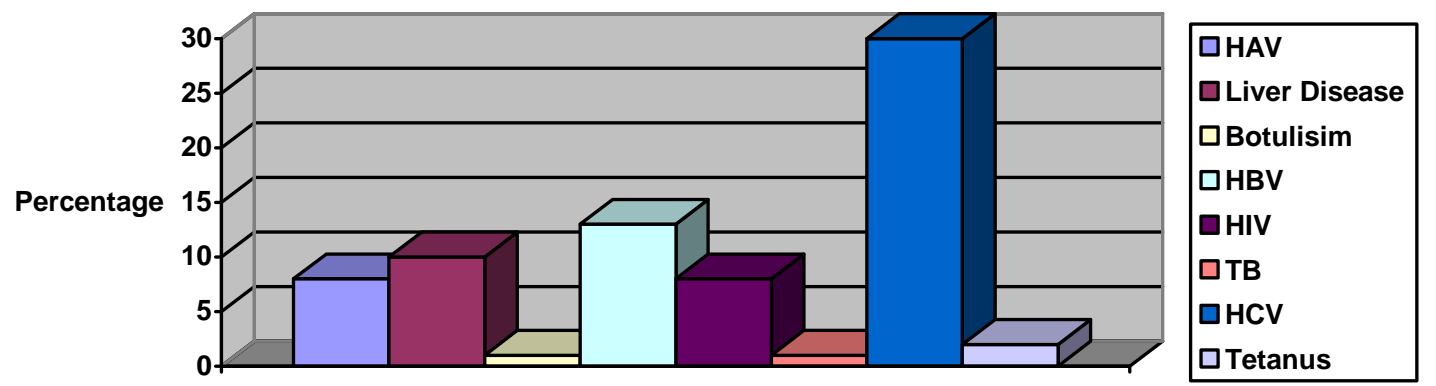

\section{BBV testing requested}

Over half of all clients requested testing for Hepatitis B and C and HIV,

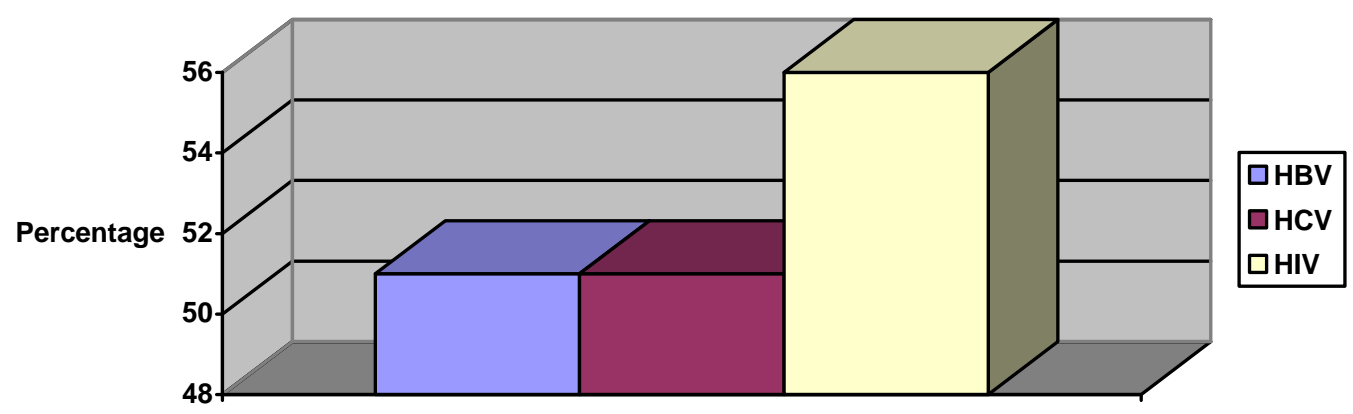

\section{Vaccinations - reported}

Hepatitis B vaccination was most frequent among clients.

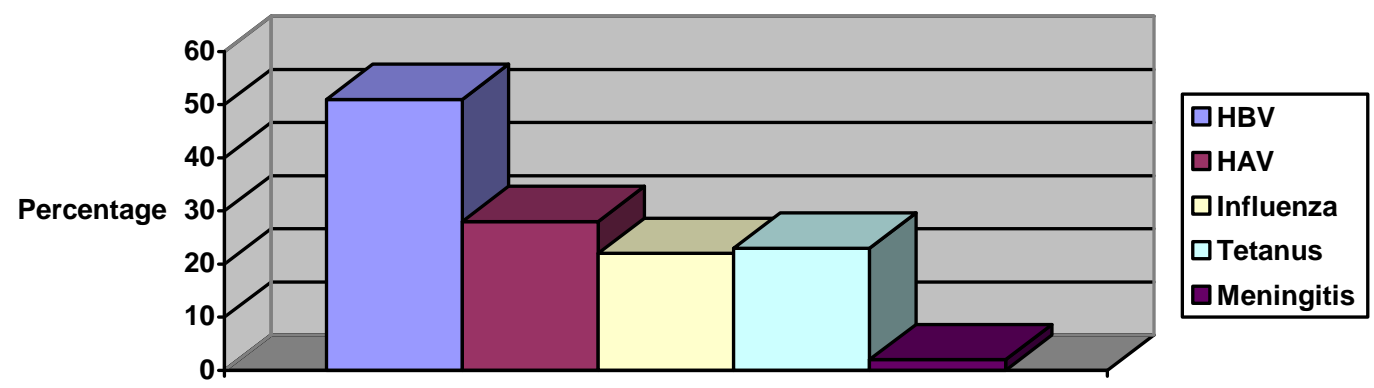




\section{Vaccinations - wanted}

About a quarter of all clients requested vaccination.

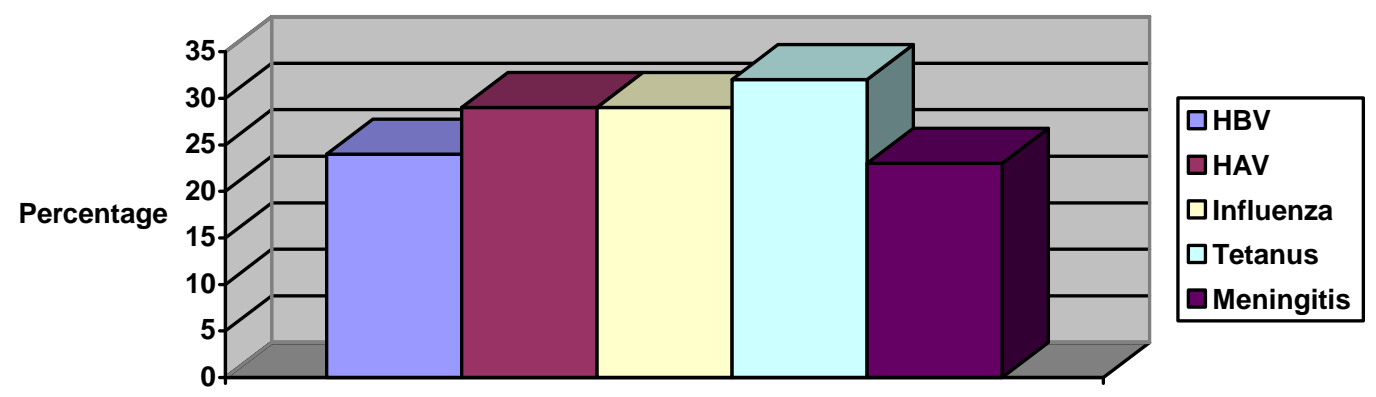

\section{Overdose}

One third of clients had deliberately taken an overdose at some point.

Half of all clients stated that they knew what to do with someone who had overdosed.

Two thirds of clients wanted further training in what to do with someone who has overdosed.

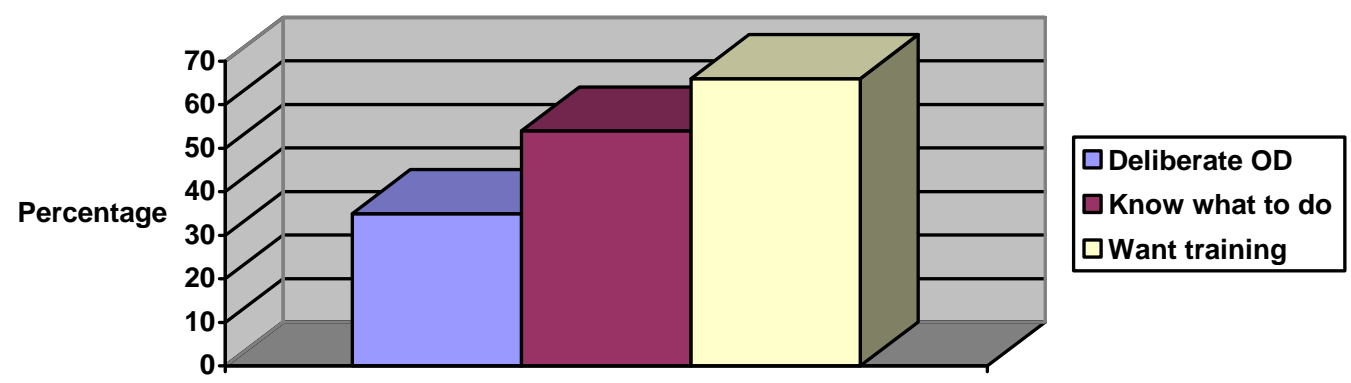




\section{DRUG \& ALCOHOL HEALTH CARE TEAM \\ CLIENT HEALTH NEEDS ASSESSMENT}

\begin{tabular}{|l|l|l|}
\hline Date: & Location: & Assessor: \\
\hline Name: & D.O.B: \\
\hline Address: & GP: \\
Homeless: Yes $\quad$ No $\quad \square$ & \\
\hline Age: & Height: \\
\hline Gender: & Weight: \\
\hline Ethnicity: & BMI: \\
\hline Language: & \\
\hline
\end{tabular}

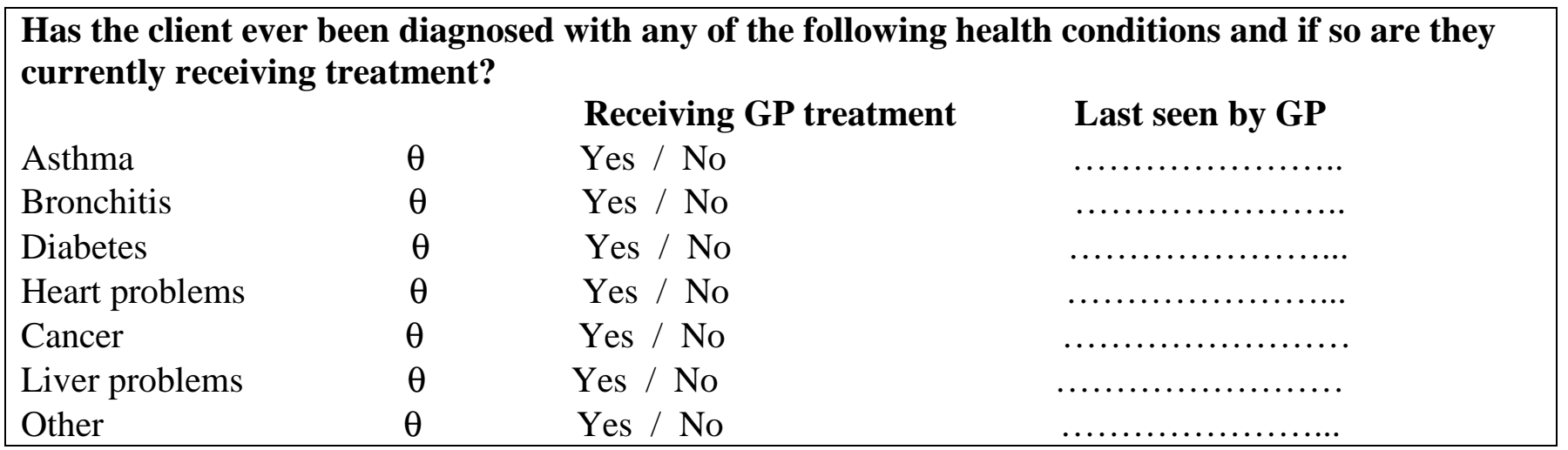

Does the client currently or have they ever experienced any of the following drug related health conditions?

(circle current health conditions)

Venous ulcers $\square \quad$ Endocarditis $\quad \square \quad$ Septicaemia $\quad \square \quad$ Abscesses $\square$

DVT $\square \quad$ Fungal skin infection $\square \quad$ Bacterial skin infection $\square$ Cellulitis

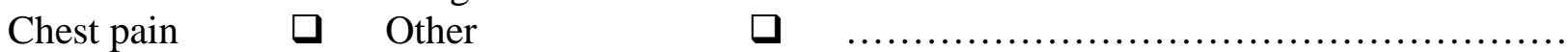

Has the client ever tested positive or been previously diagnosed with any of the following?

\begin{tabular}{|ll|lc|lc|}
\hline Hepatitis A & $\square$ & Liver disease & $\square$ & Botulism & $\square$ \\
\hline Hepatitis B & $\square$ & HIV & $\square$ & Tuberculosis & $\square$ \\
\hline Hepatitis C & $\square$ & Tetanus & $\square$ & & \\
\hline
\end{tabular}

Does the client wish to be tested for any of the following blood borne virus's?

Hepatitis B

Hepatitis C

HIV 


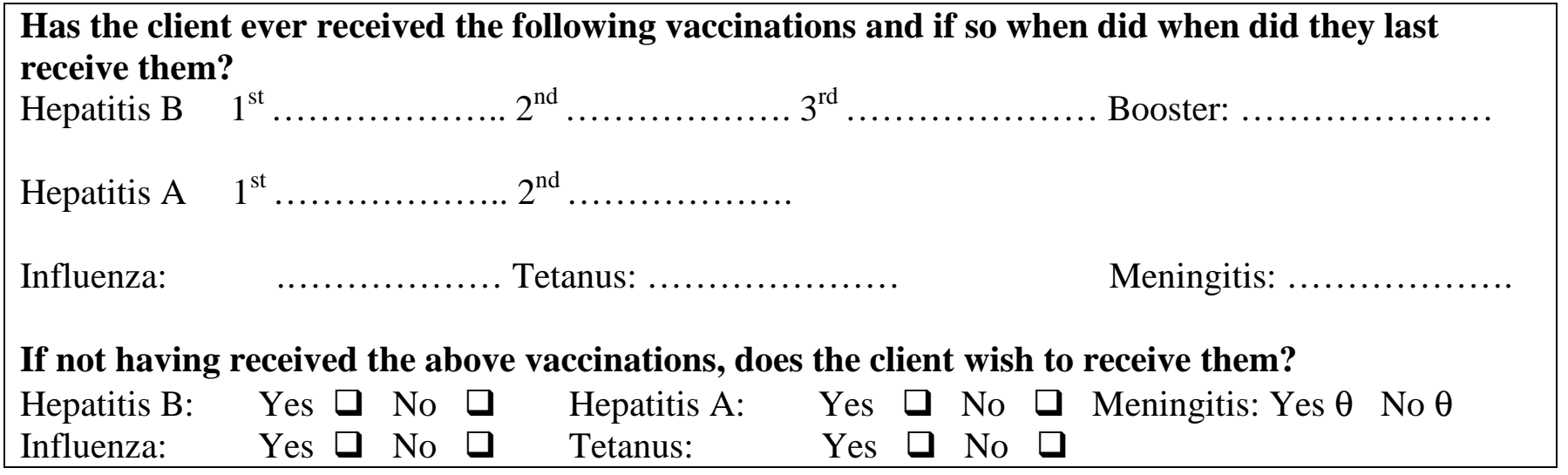

Does the client currently or have they ever suffered from any of the mental illnesses listed below? Depression $\theta \quad$ Schizophrenia $\theta \quad$ Bipolar disorder $\theta \quad$ Anxiety $\theta$ Personality disorder $\theta$

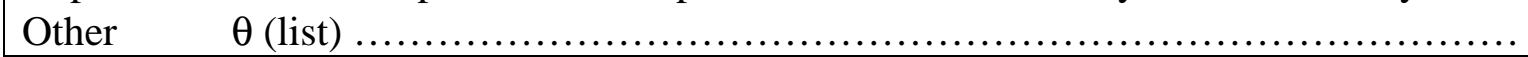

\begin{tabular}{|c|c|}
\hline $\begin{array}{l}\text { Is the client concerned about the state of their teeth? } \\
\text { Is the client currently registered with a dentist? } \\
\text { When did the client last have a dental check up? }\end{array}$ & $\begin{array}{l}\text { Yes } \square \text { No } \square \\
\text { Yes } \square \text { No } \quad \square \\
<3 \text { yrs ago } \quad \square \quad 3 \text { yrs ago } \square\end{array}$ \\
\hline $\begin{array}{l}\text { Does the client smoke? } \\
\text { If yes, what do you smoke? } \\
\text { If yes, does the client wish to give up? } \\
\text { Is the client aware of any smoking cessation services? }\end{array}$ & $\begin{array}{l}\text { Yes } \square \text { No } \square \\
\text { How much do you smoke? ........ } \\
\text { Yes } \square \text { No } \square \\
\text { Yes } \square \text { No } \square\end{array}$ \\
\hline
\end{tabular}

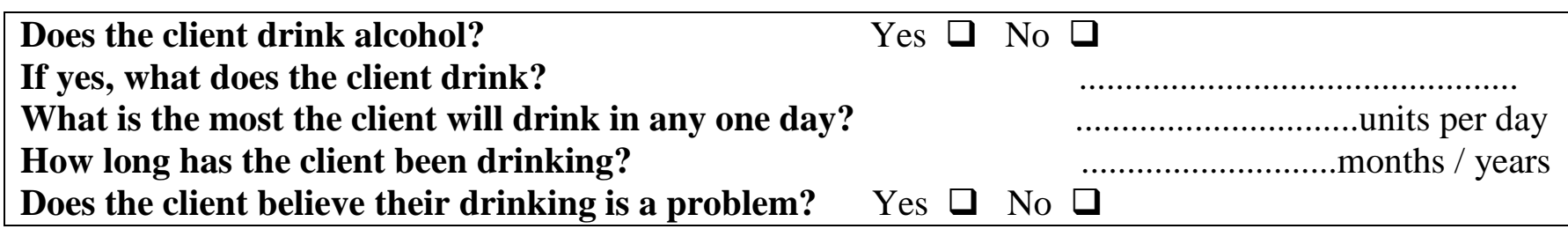

\begin{tabular}{|c|c|c|c|c|}
\hline \multicolumn{5}{|c|}{ Which of the following illicit substances did the client use in the last month? } \\
\hline & & Quantity (£) & Frequency & Route \\
\hline$\square$ & Cannabis & ................... & .................... & ................... \\
\hline$\square$ & Crack & .......... & & \\
\hline$\square$ & Cocaine & .......... & ......... & \\
\hline$\square$ & Ecstasy & ..... & & \\
\hline$\square$ & Heroin & ........ & & ….......... \\
\hline$\square$ & Methadone & & $\ldots \ldots \ldots \ldots \ldots \ldots$ & \\
\hline$\square$ & Valium & ………… & ................. & ………... \\
\hline$\square$ & (Other) ................ & 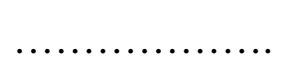 & $\ldots \ldots \ldots+\ldots$ & $\ldots \ldots \ldots+\ldots \ldots \ldots$ \\
\hline
\end{tabular}




\begin{tabular}{|llllll|}
\hline Has the client ever accidentally or deliberately taken an overdose? & Yes & $\square$ & No & $\square$ \\
Does the client know what to do if someone takes an overdose? & Yes & $\square$ & No & $\square$ \\
Would the client be interested in receiving overdose training? & Yes & $\square$ & No & $\square$ \\
\hline
\end{tabular}

\begin{tabular}{|lcccc}
\hline Has the client ever injected? & Yes & $\theta$ & No & $\theta$ \\
Has the client ever shared any drug using paraphernalia? & Yes & $\square$ & No & $\square$
\end{tabular}

If yes,

What?

Why?

Is the client aware of a needle exchange service they have access to? $\quad$ Yes $\quad \square \quad$ No

Does the client currently or have they ever experienced any of the following STI's?

Gonorrhoea $\square$ Genital warts $\square$ Genital herpes $\square$ Chlamydia $\square$ Syphilis $\square$ Thrush

Is the client aware of G.U.M services and how to access them? $\quad$ Yes $\square$ No

Does the client have any other suggestions as to how we can best develop our service to meet the physical health care needs of substance users? 